\title{
The Implementation of Mass Media Digital Platform in Indonesia
}

\author{
Woro Harkandi Kencana ${ }^{1)}$ Meisyanti ${ }^{2)}$ \\ ${ }^{1}$ Universitas Persada Indonesia YAI \\ a)Woro.harkandi@gmail.com \\ ${ }^{2}$ Universitas Persada Indonesia YAI
}

DOI:https://doi.org/10.18196/jkm.122038

Article Info

Article history: Received 14 Sep 2020 Revised 5 Nov 2020 Accepted 24 Nov 2020

\section{ABSTRACT}

Communication technology in mass media has experienced rapid development. The implementation of digital platforms is carried out by mass media groups in facing competition between media in welcoming society 5.0. This study aims to find out the implementation of digital platforms is carried out by mass media groups in Indonesia through an umbrella perspective. The research method used qualitative approach applying data collection techniques of observation, interviews, and documentation. Interviews were conducted with the person in charge of the digital platform in the media groups. Observations were also taken in the digital platform in the media groups: TransMedia Group, MNC Group, Media Group, Viva Group, Kompas Group, Emtek Group, Jawa Post Group, Netmediatama group, and Mahaka Group. The results of this study show that the forms of the current mass media digital platforms used are websites, online media, applications, and social media. In the infrastructure of media organizations, digital platforms are a form of media group policy in converting technology, content convergence, and economic convergence. Digital platforms have also provided new low-cost income for the media as an industry as well as a two-way form of communication in forming and maintaining relationships with audiences.

Keywords: Convergence of Media; Digital Platform; Mass Media Group

\section{ABSTRAK}

Teknologi komunikasi pada media massa mengalami perkembangan pesat. Implementasi platform digital dilakukan oleh grup media massa dalam menghadapi persaingan antar media dan memasuki society 5.0. Penelitian ini ingin mengetahui bagaimana implementasi platform digital yang dilakukan oleh grup media massa di Indonesia melalui perspektif umbrella. Metode penelitian menggunakan pendekatan kualitatif dengan teknik pengumpulan data observasi, wawancara dan dokumentasi. Wawancara dilakukan kepada penanggung jawab platform digital di dalam grup media dan melakukan observasi platform digital pada grup media: Trans Media Group, MNC Group, Media Group, Viva Group, Kompas Group, Emtek Group, Jawa Pos Group, Netmediatama Group dan Mahaka Group. Hasil penelitian ini bentuk dari platform digital media massa saat ini yaitu: website, media online, aplikasi dan media sosial. Pada infrastruktur organisasi media, platform digital merupakan bentuk kebijakan grup media dalam melakukan konvergensi teknologi, konvergensi konten dan konvergensi ekonomi. Platform digital juga telah memberikan pemasukan baru dengan low cost bagi media sebagai sebuah industri serta bentuk komunikasi dua arah dalam membentuk dan mempertahankan hubungan dengan audiens.

Kata Kunci: Grup Media Massa; Konvergensi Media; Platform Digital 


\section{INTRODUCTION}

Digital platform creates a new form of mass media in providing information for the society. The media groups existing in Indonesia have implemented the use of digital platform. Ross Tapsell (2017) in Media Power in Indonesia: Oligarchs, Citizens and the Digital Revolution, states that major media companies existing in Indonesia today are CT Corp, Global Mediacom, EMTEK, Visi Media Asia, Media Group, Berita Satu Media Holding, Jawa Pos, and Kompas Gramedia. Tapsell divides them into two groups based on their tracks toward the digital conglomerate title: First, through television, and second through printed media. According to Tapsell, television station is able to invest more quickly in the media platform they have already owned previously. In the printed media track, digital platform is a must in the middle of digital platform hit and the decrease of newspaper circulation (Tapsell, 2017).

In Indonesia, Sinar Harapan daily newspaper closed its business on 1 January 2016 followed by Bola, Soccer, Jurnal Nasional, Tajuk Magazine, Prospek, and Fortune. Printed media must be able to define itself from its medium. Printed media should not be simply a paper. Its power and value are not limitedly in control of the content and its distribution. Another strategy taken by the printed media is by integrating newspaper content into electronic tablets (Kusuma, 2016). Digita Subscription Kompas.id News Portal has recently added two new desks to handle news production at Kompas.id, namely daily digital desk and weekly digital desk. Meanwhile, in terms of content, Kompas.id is designed to be more diverse by utilizing technology to create multimedia and interactive content. Based on the Nielsen Consumer Media View's survey, the increase in daily consumption of dual screens can be found in all age groups. Even in the age group of 50 years and above, those having dual-screen every day increased from $7 \%$ in 2015 to $48 \%$ in 2017 (Dhiya et al., 2018).

These data also show that television screens are no longer the main choice for people to enjoy information and entertainment. As a result, electronic media channels, especially television and radio, have their digital platforms through websites and applications. Television Free to Air (FTA), which is a member of media groups such as TV One and ANTV, has a website www.antvklik.com and the MNC group with the recently launched digital platform of RCTI Plus. Meanwhile, radios in the FM frequency such as Prambors, Gen FM, and Trax FM also have websites and their broadcast streaming applications.

The consequences of convergence in Indonesia are important for two main reasons: First, the way that oligarchic groups of media owners directly build the industry through convergence. Second, the popularity of social media and citizen journalism in Indonesia has become a part of the mainstream multiplatform media sites. Previous digitalization of media entities was a specialty. However, currently, it becomes a huge multiplatform news provider. It has many implications for media freedom, including the increase of ownership concentration. In this study, it is also expected that digitalization can bring greater diversity. Through more online media channels and television, there is a significant evidence to suggest that industrial journalism will indeed remain the dominant paradigm in Indonesia in the convergence era (Tapsell, 2015). The internet has made it easier for the journalistic process which is started with the searching. Initial ideas can be facilitated by the power of internet-based data search engines. Until the work process in the field, the internet makes it easier for journalists to search data in the field, distribute journalistic works to the editorial desk, and publish journalistic works to the public more massively without being limited by space and time (Lestari, 2019).

Indonesian society is currently in a transition phase toward the information era society. In this process, there is a shift in people's pattern in accessing and distributing information. It is a lifestyle change as a consequence of using communication devices of information technology-based (ICT) (Respati, 2014). In the technological architecture, it is necessary to determine the architectural patterns and data protocols on mass media technology in Indonesia. One of them is that television stations will determine architectural patterns and data protocols using technology-based on Service Oriented Architecture (SOA) since each service in SOA can communicate with each other regardless of the technology platform used by the service. If there is a change, only the related services will change so that it does not affect the whole system (Setiawan et al., 2015).

Today's innovative communication device features offer an increasingly interactive medium of communication. One of the most vital features is Blog, a web 2.0-based social media application, providing the capacity to produce and distribute information that encourages people to take an active role not only in consuming but also producing news just like professional journalists. The mainstream 
media industry practitioners facing this phenomenon must not ignore the shift in audience behavior in consuming and distributing information. They also cannot resist the rise of the era of virtual communities and citizen reporters. In the era of the information society, mainstream media practitioners must accept it by transforming into news media that provides creative space for their audience to actively participate in producing information.

The ICT development requires mass media to be more creative in processing and presenting news according to changes in people's tastes. At the end, new media emerges as a medium that always grows rapidly and is in high demand among the public in various circles. The success of new media often generates critical reactions, especially when the media adopts a questionable competitive strategy in producing content and attracting consumers (Pratiwi, 2014).

This research highlights the implementation of digital platforms with the object of research, namely the mass media in Indonesia, especially the major media groups in Indonesia. In this case, this research is also related to the convergence taken by major media groups in Indonesia where the convergence has combined several mass media that can be accessed with one platform, namely a digital platform which is certainly easier and faster for the audience in fulfilling their needs.

In this research, it emphasizes the process of implementing a digital platform through an umbrella perspective in order to identify the various levels of society in comprehending communication technology. Communication Technology Perspective umbrella is introduced by Everett M. Rogers and Sandra J Ball-Rokeach's writing on communication technology. At the very bottom level, they are software and hardware. The second lowest level is the organizational infrastructure and the top level is the social, political, economic, and media systems. In the umbrella perspective image, there is an umbrella handle which the contents are the writing of the users or the digital communication technology users (Nurudin, 2017).

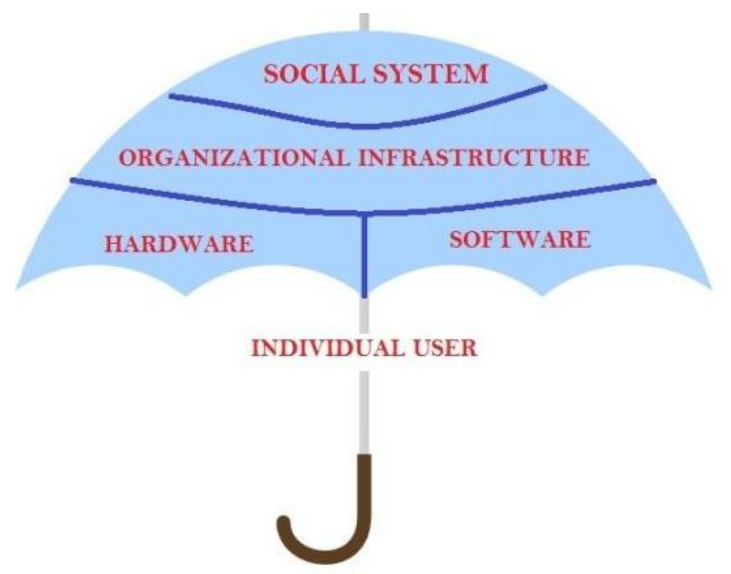

Figure 1. Umbrella Perspective

(Source: Nurudin, 2017)

Another previous study focusing only on television media is the implementation of communication technology on the digital television broadcast media platform conducted by $\mathrm{WH}$. Kencana. In this study, the results show that the digital television platform is a new media that brings the television industry into the 4.0 era. Through the umbrella perspective, it helps to identify various levels of the society in understanding communication technology. At the lowest level, there is hardware to receive information through television. The device is television as an electronic device and digital media platform, namely smartphones, tablets, laptops, and individual computers. Meanwhile, software is a form of digital television platform, among others: television online websites that do not only provide information to the audience but also becomes a different form of screen display in receiving television shows through live streaming. The social media form as an interactive media and applications as a digital platform become an integration of the two previous platforms as an interactive platform between the television station and its audience as well as the live streaming feature and video on demand. Digital platforms in television media are a new media category as a form of interpersonal communication media, interactive game media, information-seeking media, collective participation media, and broadcast media substitution with a wider audience coverage (Kencana, 2018). 
The next level in the umbrella perspective is the infrastructure of the broadcasting organization as a digital platform provider. Several media groups have converged media into digital platforms by using one application or website together. This organizational level is influenced by the top level, namely the social and economic system in which media groups compete each other in obtaining ad portions, brand image, and audience by continuously developing technology on this digital platform. This is supported by users as the foundation where society has entered the digital era as an information society applying digital platforms to fulfil the need for information that is easier, faster, and accessible at any time.

On the other hand, this study also used a communication technology implementation model involving three processes, namely redefining, clarifying, and routinizing. Redefining is defined as regulating, arranging, and even modifying the organizational structure (for institutions) or mental and habits (for individuals) for the intended communication technology purposes. The next stage is clarifying, which is to convince all members (for institutions) or themselves (for individuals) about the ins and outs of the communication technology in question, so that communication technology does not become something odd. To be applicable, there must be a process that ensures the new communication technology is important to be implemented. The last stage of the implementation process is routinizing, where communication technology is clearly known and becomes a part of an organization's infrastructure (for institutions) or a complement to daily life (for individuals). This technology has become a habit in daily work procedures (for institutions) and a part of information actors (for individuals) (Nurudin, 2017).

The problem in this research is how the major mass media groups in Indonesia perform the process of implementing communication technology on their digital platforms in the midst of increasingly fierce media competition. The specific purpose of this study is to identify and analyze the implementation and development of digital mass media platforms in major media groups in Indonesia until 2020. The forms of mass media in this study are television, radio, newspapers, and news portals.

\section{METHODS}

The method in this study used descriptive qualitative approach. A qualitative approach in epistemology requires the researchers to interact with what is being studied. The researcher serves as a research instrument. Meanwhile, the assumption of the qualitative approach methodology is an inductive process, continuous explanations sharpening, continuous research designs development during the research, attention of context, patterns identification, theories formulation, and verification - triangulation (Imran, 2015).

The process of data management and analysis will be done by the chairman and the researcher who are grouped according to the categories of questions that were compiled in the interview and adjusted to the observations that have been made. The object of research was the implementation of the digital platform used by mass media groups in Indonesia. The research units consisted of nine major media groups that have various forms of mass media, namely: newspapers, television, radio, news portals, and other digital applications. These media groups: TransMedia Group, Kompas Group, MNC Group, Media Group, Emtek Group, Mahaka Group, Viva Group, Netmediatama, and Jawa Pos Group. The data collection techniques consist of primary and secondary data. For primary data, conducting in-depth interviews is limited to the person in charge of the digital platform of the media groups, namely: Trans Media Group, Kompas Group, MNC group, Media Group, and Emtek Group. In this study, the type of observation applied was non-participant observation, which is an observation in which the researcher does not position himself as a member of the group being studied or the researcher only acts as an observation without participating in activities of the group being researched, whether his presence is known or not (Kriyantono, 2014). The observations were done on the research objects, namely the digital platform of the nine mass media groups. Meanwhile, secondary data was collected through literature study and documentation.

According to Sarwono, the qualitative analysis procedure consists of five steps. First, organizing the collected data carefully. Second, creating categories and determining themes and patterns. Third, testing hypotheses using the information coming up with the existing data. Fourth, looking for rational explanations from the data based on the correct logic of meaning. Five, writing reports using the appropriate words, phrases, and sentences (Dianna, 2020). 


\section{RESULT AND DISCUSSION}

The digital platform in the mass media is the policy of the media group in entering the digital era and facing competition between media. The multiplatform expansion strategy is driven by expectations among media managers that there are opportunities to generate new revenue, improve the management, and create a cost-effective exploitation of media resources. The multiplatform approach means that new ideas for content are considered in the context of various distribution possibilities and not limitedly of conventional platforms such as printed and electronic media which still last in linear ways in message delivery. When a printed publisher becomes a multiplatform publisher, it does not only provide paper-based products but also digital edition with additional features such as video.

For electronic media, becoming a multiplatform supplier requires content delivery in a new form and format that is compatible with digital platforms series which currently can be selected by audience in accessing the desired content. The shift into digital platforms, which involves two-way connectivity (dialogical interfaces), has obliged and required a new way of thinking of the media managers and strategists, rather than focusing on media production and distribution. Content is a consideration recently serving an important position and a way to build and maintain relationship with audiences (Gillian, 2010).

\section{Software and Hardware of the Digital Platform}

The results of this study view the process of the implementation of a digital platform through an umbrella perspective. Communication Technology Perspective umbrella is initiated by Everett $\mathrm{M}$. Rogers. At the very bottom level, they are software and hardware. Hardware on a digital platform is a tool used in delivering and receiving information messages over the internet network. In this case, the hardware used is personal computers, mobile phones, tablets and laptops. Meanwhile, the software is in the form of a digital platform of mass media. The researchers classify these digital platforms, among others: websites - online media, applications, and social media. The first are websites and online media. Basically, all types of media connected to the internet are known as online media. In this study, online media, specifically in the context of mass media, is news and information websites, news portals, or online newspapers and magazines.

On the other hand, a website is a type of online media defined as a page that contains a variety of information in one web domain. In this study, the researchers combined online media and websites. The second is an application defined as a software or computer program that operates on particular systems that are created and developed to perform certain commands. In this study, the application is in the form of a mobile application, which is an application that is run on a mobile device. Thus, the users can access it portably. The access to mobile applications can be downloaded using the Play Store for Android systems or the App Store for Apple device users. The third is social media, which is an online forum functioning as a means of sharing or exchanging information, commenting on each other, and forming a community. The online media used are Facebook, Twitter, Instagram, Tik Tok and YouTube. The form of the nine media group digital platforms are presented in the following table.

Table 1. Digital Platform of Transmedia Group

(Source: researcher's observation *FTA: Free to Air)

\begin{tabular}{|c|c|c|c|c|c|}
\hline \multirow{2}{*}{\multicolumn{2}{|c|}{ Media Group }} & \multirow{2}{*}{$\begin{array}{c}\text { Television } \\
\text { Program }\end{array}$} & \multicolumn{3}{|c|}{ Digital Platform } \\
\hline & & & Website/Online Media & Application & $\begin{array}{l}\text { Social } \\
\text { Media }\end{array}$ \\
\hline \multirow{8}{*}{$\begin{array}{l}\text { Transme- } \\
\text { dia Group }\end{array}$} & \multirow[t]{2}{*}{ FTA* } & Trans TV & www.transtv.co.id & - & \multirow{8}{*}{$\begin{array}{l}\text { Facebook, } \\
\text { Instagram, } \\
\text { Twitter and } \\
\text { YouTube }\end{array}$} \\
\hline & & Trans 7 & www.trans7.co.id & - & \\
\hline & \multirow{2}{*}{$\begin{array}{l}\text { Channel } \\
\text { TV }\end{array}$} & CNN TV & www.cnnindonesia.com & $\mathrm{CNN}$ Indonesia & \\
\hline & & CNBC & www.cnbcindonesia.com & CNBC Indonesia & \\
\hline & Pay TV & Transvision & www.transvision.co.id & Transvision & \\
\hline & \multirow{3}{*}{$\begin{array}{l}\text { Online } \\
\text { Media }\end{array}$} & Hi Bunda & www.HaiBunda.com & - & \\
\hline & & InsertLive & www.InsertLive.com & - & \\
\hline & & Detik & www.detik.com & Detik.com & \\
\hline
\end{tabular}




\section{DETIK}

Pasang Mata

Table 2. Digital Platform of Global Media Com (MNC)

(Source: researcher's observation *FTA: Free to Air)

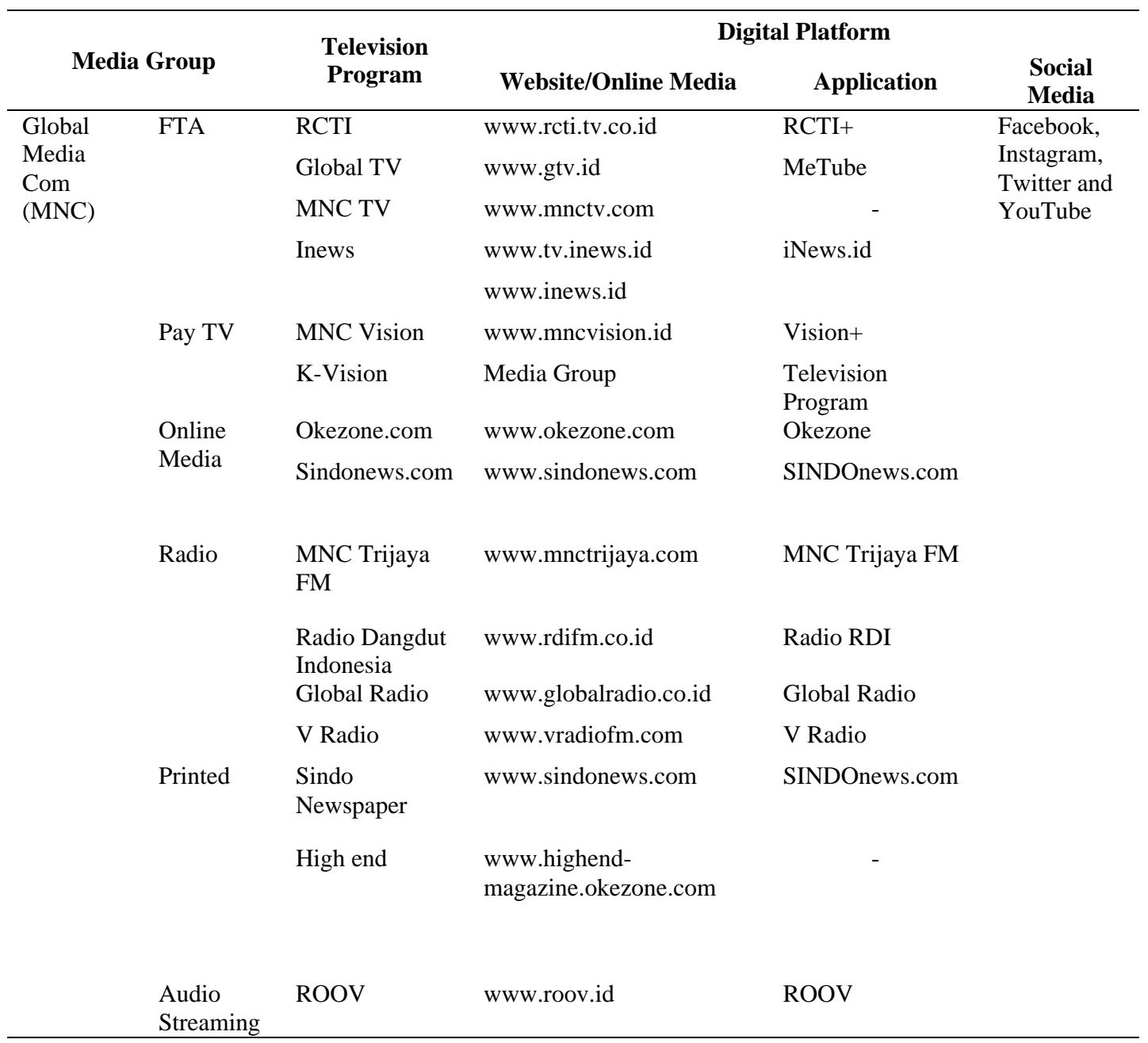

Table 3. Platform Digital Elang Mahkota Teknologi (EMTEK) (Source: researcher's observation *FTA: Free to Air)

\begin{tabular}{|c|c|c|c|c|c|}
\hline \multirow{2}{*}{\multicolumn{2}{|c|}{ Media Group }} & \multirow{2}{*}{$\begin{array}{l}\text { Television } \\
\text { Program }\end{array}$} & \multicolumn{3}{|c|}{ Digital Platform } \\
\hline & & & Website/Online Media & Application & Social Media \\
\hline \multirow{8}{*}{$\begin{array}{l}\text { Elang } \\
\text { Mahkota } \\
\text { Teknologi } \\
\text { (EMTEK) }\end{array}$} & \multirow[t]{2}{*}{ FTA } & SCTV & www.sctv.co.id & Vidio & \multirow{8}{*}{$\begin{array}{l}\text { Facebook, } \\
\text { Instagram, } \\
\text { Twitter, and } \\
\text { YouTube. } \\
\text { Indosiar has } \\
\text { Tik Tok }\end{array}$} \\
\hline & & Indosiar & www.indosiar.com & & \\
\hline & $\begin{array}{l}\text { Local } \\
\text { TV }\end{array}$ & O Channel & www.ochanneltv.com & - & \\
\hline & \multirow{5}{*}{$\begin{array}{l}\text { Online } \\
\text { Media }\end{array}$} & Liputan6.com & www.liputan6.com & Liputan6.com & \\
\hline & & KapanLagi.com & www.kapanlagi.com & - & \\
\hline & & Bola.net & www.bola.net & - & \\
\hline & & Merdeka.com & www.merdeka.com & - & \\
\hline & & Bola.com & www.bola.com & - & \\
\hline
\end{tabular}




\begin{tabular}{llll}
\hline Dream.co.id & www.dream.co.id & - \\
\cline { 2 - 3 } Fimela.com & www.fimela.com & - \\
\hline Otosia.com & www.otosia.com & - \\
\hline Brilio.net & www.brilio.net & Brilio.net \\
\hline
\end{tabular}

Table 4. Digital Platform of Media Group

(Source: researcher's observation *FTA: Free to Air)

\begin{tabular}{|c|c|c|c|c|c|}
\hline \multirow{2}{*}{\multicolumn{2}{|c|}{ Media Group }} & \multirow{2}{*}{$\begin{array}{c}\text { Television } \\
\text { Program }\end{array}$} & \multicolumn{3}{|c|}{ Digital Platform } \\
\hline & & & Website/Online Media & Application & $\begin{array}{l}\text { Social } \\
\text { Media }\end{array}$ \\
\hline \multirow[t]{8}{*}{$\begin{array}{l}\text { Media } \\
\text { Group }\end{array}$} & FTA & Metro TV & www.metrotvnews.com & $\begin{array}{l}\text { Metro TV } \\
\text { News }\end{array}$ & $\begin{array}{l}\text { Facebook, } \\
\text { Instagram, }\end{array}$ \\
\hline & Digital TV & $\begin{array}{l}\text { Magna } \\
\text { Channel }\end{array}$ & - & - & $\begin{array}{l}\text { Twitter, and } \\
\text { YouTube }\end{array}$ \\
\hline & & $\begin{array}{l}\text { Business } \\
\text { News TV } \\
\text { (BNN TV) }\end{array}$ & - & - & \\
\hline & Online Media & Medcom.id & www.medcom.id & Medcom ID & \\
\hline & & Inibaru.id & www.inibaru.id & - & \\
\hline & Printed & $\begin{array}{l}\text { Media } \\
\text { Indonesia }\end{array}$ & www.mediaindonesia.com & $\begin{array}{l}\text { Media } \\
\text { Indonesia }\end{array}$ & \\
\hline & & $\begin{array}{l}\text { Lampung } \\
\text { Post }\end{array}$ & www.lampost.co & Lampung Post & \\
\hline & $\begin{array}{l}\text { Audio } \\
\text { Streaming }\end{array}$ & Podme & www.podme.id & Podme & \\
\hline
\end{tabular}

Table 5. Digital Platform of Jawa Pos

(Source: researcher's observation *FTA: Free to Air)

\begin{tabular}{|c|c|c|c|c|c|}
\hline \multirow{2}{*}{\multicolumn{2}{|c|}{ Media Group }} & \multirow{3}{*}{$\begin{array}{c}\begin{array}{c}\text { Television } \\
\text { Program }\end{array} \\
\text { Jawa Post TV }\end{array}$} & \multicolumn{3}{|c|}{ Digital Platform } \\
\hline & & & Website/Online Media & Application & $\begin{array}{l}\text { Social } \\
\text { Media }\end{array}$ \\
\hline \multirow[t]{12}{*}{ Jawa Pos } & Local TV & & www.jawapos.tv & JPM STREAM & \multirow{10}{*}{$\begin{array}{l}\text { Facebook, } \\
\text { Instagram, } \\
\text { Twitter, and } \\
\text { YouTube }\end{array}$} \\
\hline & & JTV & www.jawapos.tv & - & \\
\hline & & $\begin{array}{l}\text { Some Local TV in } \\
\text { Provinces in } \\
\text { Indonesia }\end{array}$ & & & \\
\hline & \multirow[t]{7}{*}{ Printed } & \multirow[t]{2}{*}{ Jawa Pos } & \multirow[t]{2}{*}{ www.jawapos.com } & JawaPos.com & \\
\hline & & & & $\begin{array}{l}\text { Jawa Pos } \\
\text { Digital } \\
\text { Newspaper }\end{array}$ & \\
\hline & & Indopos & www.indopos.id & - & \\
\hline & & Rakyat Merdeka & www.rmco.id & - & \\
\hline & & Lampu Hijau & www.lampuhijau.co.id & - & \\
\hline & & The Jak & - & - & \\
\hline & & $\begin{array}{l}\text { Some Newspapers } \\
\text { in Provinces in } \\
\text { Indonesia }\end{array}$ & & & \\
\hline & \multirow[t]{2}{*}{ Radio } & KPFM & www.968kpfm.co.id & - & \\
\hline & & $101 \mathrm{KPFM}$ & www.kpfmpalangkaraya. & - & \\
\hline
\end{tabular}




\begin{tabular}{|c|c|c|c|}
\hline & $\begin{array}{l}\text { (Central } \\
\text { Kalimantan Pos } \\
\text { Radio) }\end{array}$ & com & \\
\hline & Fajar FM & - & - \\
\hline $\begin{array}{l}\text { Online } \\
\text { Media }\end{array}$ & JPNN.com & www.jpnn.com & JPNN.com \\
\hline
\end{tabular}

Table 6. Digital Platform of Kompas Gramedia

(Source: researcher's observation *FTA: Free to Air)

\begin{tabular}{|c|c|c|c|c|c|}
\hline & & Tol-vicion & & igital Platform & \\
\hline Medi & Group & Program & $\begin{array}{c}\text { Website/Online } \\
\text { Media }\end{array}$ & Application & $\begin{array}{l}\text { Social } \\
\text { Media }\end{array}$ \\
\hline Kompas & FTA & Kompas TV & www.kompas.tv & Kompas TV & Facebook, \\
\hline Gramedia & Local TV & $\begin{array}{l}\text { KTV (Televisi } \\
\text { Kota Kita) }\end{array}$ & www.ktv.co.id & - & $\begin{array}{l}\text { Instagram, } \\
\text { Twitter, and }\end{array}$ \\
\hline & Pay TV & K-Vision & www.k-vision.tv & My K-Vision & \\
\hline & Printed & $\begin{array}{l}\text { Kompas } \\
\text { Newspaper }\end{array}$ & www.kompas.id & Kompas.id & \\
\hline & & Intisari & www.intisari.grid.id & - & \\
\hline & & Kontan & www.kontan.co.id & Kontan & \\
\hline & & Bobo & www.bobogrid.id & - & \\
\hline & & Otomotif & $\begin{array}{l}\text { www.otomotifnet.grid } \\
\text { oto.com }\end{array}$ & - & \\
\hline & & Nova & www.nova.grid.id & - & \\
\hline & & Sedap & $\begin{array}{l}\text { www.sajiansedap.grid } \\
\text {.id }\end{array}$ & - & \\
\hline & & Tabloid Kontan & www.kontan.co.id & - & \\
\hline & & Warta Kota & $\begin{array}{l}\text { www.wartakota.tribun } \\
\text { news.com }\end{array}$ & Wartakotalive.com & \\
\hline & & Surya & www.surabaya.tribun & - & \\
\hline & & Newspaper & news.com & & \\
\hline & & Serambi & $\begin{array}{l}\text { www.acehtribunnews. } \\
\text { com }\end{array}$ & - & \\
\hline & & $\begin{array}{l}\text { Banjarmasin } \\
\text { Post }\end{array}$ & $\begin{array}{l}\text { www.banjarmasin.trib } \\
\text { unnews.com }\end{array}$ & - & \\
\hline & & Bangka Pos & $\begin{array}{l}\text { www.bangka.tribunne } \\
\text { ws.com }\end{array}$ & - & \\
\hline & & Pos Belitung & $\begin{array}{l}\text { www.belitung.tribunn } \\
\text { ews.com }\end{array}$ & - & \\
\hline & & Pos Kupang & $\begin{array}{l}\text { www.kupang.tribunne } \\
\text { ws.com }\end{array}$ & - & \\
\hline & & $\begin{array}{l}\text { Tribun (Some } \\
\text { Cities) }\end{array}$ & - & - & \\
\hline & & Mombi & - & - & \\
\hline & & Creativity & & & \\
\hline & & Magazine & & & \\
\hline & & $\begin{array}{l}\text { Bobo Junior } \\
\text { Magazine }\end{array}$ & - & - & \\
\hline & & National & www.nationalgeograp & - & \\
\hline & & Geographic & hic.grid.id & & \\
\hline & & Indonesia & & & \\
\hline & & National & - & - & \\
\hline & & Geographic & & & \\
\hline & & KiDS & & & \\
\hline & & iDEA & www.idea.grid.id & - & \\
\hline
\end{tabular}




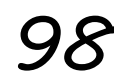

\begin{tabular}{|c|c|c|c|}
\hline & Info Komputer & $\begin{array}{l}\text { www.infokomputer.gr } \\
\text { id.id }\end{array}$ & - \\
\hline & Sedap & - & - \\
\hline & Magazine for & & \\
\hline & Beginners & & \\
\hline & Tabloid Saji & - & - \\
\hline & Super Ball & $\begin{array}{l}\text { www.superball.bolasp } \\
\text { ort.com }\end{array}$ & - \\
\hline & Motor Plus & $\begin{array}{l}\text { www.motorplus- } \\
\text { online.com }\end{array}$ & Motorplus-Online \\
\hline & JIP Magazine & www.jipgridoto.com & - \\
\hline Radio & Sonora & ww.sonora.co.id & - \\
\hline & Motion Radio & $\begin{array}{l}\text { www.motionradiofm. } \\
\text { com }\end{array}$ & - \\
\hline & $\begin{array}{l}\text { DB Radio FM } \\
\text { Cirebon }\end{array}$ & - & - \\
\hline & Smart FM & $\begin{array}{l}\text { www.radiosmartfm.co } \\
\text { m }\end{array}$ & - \\
\hline & $\begin{array}{l}\text { Radio Raka } \\
\text { Bandung }\end{array}$ & - & - \\
\hline & Kalimaya & - & - \\
\hline & Bhaskara FM & & \\
\hline & Ria FM Solo & - & - \\
\hline & Radio Palupi & - & - \\
\hline & Bali FM & - & - \\
\hline & Prima FM & - & - \\
\hline & Serambi FM & www.serambifm.com & - \\
\hline Online & Kompas.com & www.kompas.com & KOMPAS.COM \\
\hline Media & Tribunnews & www.tribunnews.com & TRIBUNnews \\
\hline & Kompasiana & $\begin{array}{l}\text { www.kompasiana.co } \\
\text { m }\end{array}$ & - \\
\hline & $\begin{array}{l}\text { Serambi } \\
\text { Indonesia }\end{array}$ & $\begin{array}{l}\text { www.acehtribunnews. } \\
\text { com }\end{array}$ & - \\
\hline & Hai Online & www.hai.grid.id & - \\
\hline & Grid.id & www.grid.id & Grid.id \\
\hline & $\begin{array}{l}\text { Cewekbanget.i } \\
\mathrm{d}\end{array}$ & $\begin{array}{l}\text { www.cewekbanget.gri } \\
\text { d.id }\end{array}$ & - \\
\hline & Foto Kita & www.fotokita.net & - \\
\hline & Nakita.id & www.nakita.grid.id & - \\
\hline & Nextren & www.nextren.grid.id & - \\
\hline & GridOto.com & www.gridoto.com & - \\
\hline & Otomania.com & $\begin{array}{l}\text { www.otomania.gridot } \\
\text { o.com }\end{array}$ & - \\
\hline & BolaSport.com & www.bolasport.com & Bolasport \\
\hline & Stylo.id & www.stylo.grid.id & - \\
\hline & $\begin{array}{l}\text { Grid Story } \\
\text { Factory }\end{array}$ & www.grid.co.id & Gridoto.com \\
\hline & Grid Games.id & www.gridgames.id & - \\
\hline
\end{tabular}


Table 7. Digital Platform of Visi Media Asia

(Source: researcher's observation *FTA: Free to Air)

\begin{tabular}{|c|c|c|c|c|c|}
\hline \multirow{2}{*}{\multicolumn{2}{|c|}{ Media Group }} & \multirow{2}{*}{$\begin{array}{l}\text { Television } \\
\text { Program }\end{array}$} & \multicolumn{3}{|c|}{ Digital Platform } \\
\hline & & & Website/Online Media & Application & Social Media \\
\hline \multirow{12}{*}{$\begin{array}{l}\text { Visi Media } \\
\text { Asia }\end{array}$} & FTA & ANTV & www.antvklik.com & VIVA & Facebook, \\
\hline & & & www.viva.co.id/antv/live & ANTV GO & Instagram, \\
\hline & & TV One & www.tvonenews.tv & VIVA & $\begin{array}{l}\text { Twitter dan } \\
\text { Youtube }\end{array}$ \\
\hline & & & www.viva.co.id/tvone/live & tvOne & \\
\hline & & & & Connect & \\
\hline & Online & Viva.co.id & www.viva.co.id & VLIX & \\
\hline & Media & Suara Merdeka & www.suaramerdeka.com & VIVA & \\
\hline & & Jago Dangdut & www.jagodangdut.com & & \\
\hline & & 100kpj & www.100kpj.com & & \\
\hline & & Intipseleb & www.Intipseleb.com & & \\
\hline & & Sahijab & www.sahijab.com & & \\
\hline & & Onepride & www.onepride.net & & \\
\hline
\end{tabular}

Table 8. Digital Platform of Net Media Tama

(Source: researcher's observation *FTA: Free to Air)

\begin{tabular}{|c|c|c|c|c|}
\hline \multirow{2}{*}{ Media Group } & \multirow{2}{*}{$\begin{array}{l}\text { Television } \\
\text { Program }\end{array}$} & \multicolumn{3}{|c|}{ Digital Platform } \\
\hline & & Website/Online Media & Application & Social Media \\
\hline $\begin{array}{ll}\text { Net Media } & \text { FTA } \\
\text { Tama } & \end{array}$ & Net TV & www.netmedia.co.id & $\begin{array}{l}\text { NET Z } \\
\text { ZULU } \\
\text { NET.CONNE } \\
\text { CT } \\
\text { NET.JALAN- } \\
\text { JALAN } \\
\text { NET.CJNET }\end{array}$ & $\begin{array}{l}\text { Facebook, } \\
\text { Instagram, } \\
\text { Twitter, and } \\
\text { YouTube }\end{array}$ \\
\hline
\end{tabular}

Table 9. Digital Platform of Mahaka Group

(Source: researcher's observation *FTA: Free to Air)

\begin{tabular}{|c|c|c|c|c|c|}
\hline \multirow{2}{*}{\multicolumn{2}{|c|}{ Media Group }} & \multirow{2}{*}{$\begin{array}{c}\text { Television } \\
\text { Program }\end{array}$} & \multicolumn{3}{|c|}{ Digital Platform } \\
\hline & & & Website/Online Media & Application & Social \\
\hline \multirow[t]{11}{*}{$\begin{array}{l}\text { Mahaka } \\
\text { Group }\end{array}$} & $\begin{array}{l}\text { FTA } \\
\text { (Local TV) }\end{array}$ & Jak TV & www.jak-tv.com & - & $\begin{array}{l}\text { Facebook, } \\
\text { Instagram, }\end{array}$ \\
\hline & Radio & Gen FM (Jakarta & www.gen $987 \mathrm{fm} . c o m$ & 987 Gen FM & Twitter, \\
\hline & & dan Surabaya) & www.gen $1031 \mathrm{fm} . c 0 m$ & 1031 Gen FM & and \\
\hline & & Jak FM & www.jak101fm.com & 101 Jak FM & \\
\hline & Printed & Republika & www.republika.co.id & Republika.co.id & \\
\hline & & Newspaper & & & \\
\hline & & Golf Digest & - & - & \\
\hline & & Indonesia & & & \\
\hline & Online & Sportku.com & www.sportku.com & - & \\
\hline & Media & & & & \\
\hline & $\begin{array}{l}\text { Audio } \\
\text { Streaming }\end{array}$ & Noice & www.noice.id & Noice & \\
\hline
\end{tabular}




\section{Mass Media Organizational Infrastructure}

The second lowest level is the organizational infrastructure. The multiplatform policy from the owner of the media group to the implementation of digital platforms in mass media groups in Indonesia leads to a form of media convergence. This media competition cannot be avoided in the midst of a free market competing for the market, advertising revenue, and investors. Media convergence is the right policy to integrate systems within institutions from a technological and professional management perspective. The forms of convergence that occur are technology convergence, economic convergence, and content convergence. Meanwhile, the convergence stage has carried out cross promotion, cloning, competition and content sharing at the full convergence stage (Kencana, 2014). Based on the results of interviews conducted by the researchers, this digital platform is integrated into one large media group as a form of convergence. Kompas Group with its multiplatform has a technology convergence with the INR. Using this technology, Kompas Group can converge content and economy. Meanwhile, for MNC, although they do not have a shared news server, content convergence occurs during the content sharing stages using the Integrated News Room (INR). This technology becomes a shared server container in processing information to be distributed based on each media platform used. This convergence was confirmed based on the results of the researcher interview with Masirom, the Editor in Chief of Inews.id who explained that the synergy of the online news portal occurred between okezone.com, sindonews.com and inews.com. This synergy occurs when they work together in the field to find news. Then, it is also built when processing the news to be presented to the audience based on the point of view of each online media.

In TransMedia group, multiplatform convergence among media groups using digital platforms. One of which is organizing joint events. This group creates conversation admins on the social media of each media. In this convergence, Cross Promotion can be done in promoting the program. The technology convergence on the use of broadcasting tools is also performed by this group.

The mass media organizations serving as the objects in this study were nine media groups in Indonesia that already have the infrastructure in the implementation of digital platforms. At this level, the researcher analyzes the communication technology implementation model consisting of three processes, namely redefining, clarifying, and routinizing. Redefining that is regulating, compiling, and even modifying the organizational structure (for institutions) or mental and habits (for individuals) for the intended communication technology purposes. Mass media organizations have included management divisions in the digital platform. In its development, this media group has created and developed a new digital platform to meet the needs of the society online.

Television and radio stations do not only broadcast messages through television screens and radio but the messages can be also accessed in websites and applications. Every TV station has an online TV website in streaming as well as the radio stations. In the first media age, radio was limited by the area frequency of the broadcast. Today, by streaming the official radio website or application, radio broadcasts can be accessed at anytime and anywhere. Mass media in this digital world also provides video and audio on demand. The programs broadcasted can be accessed again by the audience. For television shows, several media groups present the shows in the form of online video applications such as TransMedia Group with TransTv Live presenting Trans Tv and Trans7 shows and Emtek Group with the Vidio.com application broadcasting SCTV and Indosiar on demand programs. On the other hand, MNC Group has two applications in broadcasting the streaming and video on demand programs, namely MeTube and RCTI +. Meanwhile, Viva Group presents VIVA and Vlix applications for streaming the programs of tvOne and ANTV. The video on demand does not compete with national television, but complements it. This platform allows users to watch films and television series, which are only available on television broadcasts or DVD or Blu-ray, regardless any programs and schedules (Mikos, 2016).

The newest digital platform issued by the media groups is audio streaming which is also integrated with their radio broadcasts. The form of audio streaming and also on demand services is available in a form of podcasts. MNC has ROOV. This application is also linked to RCTI + application. Meanwhile, Media Group has PodMe. PodMe also implies a new audio broadcast flexibility without being restricted by any schedule and content adjustments based on the category selected. The content presented is lighter than the Media Group presentation. Meanwhile, Mahaka Group has NOICE. The applications are used to listen to radio, music and podcasts streaming for free, in which all of the contents in the application comes from the local contents 
Many online media networks have been created in each media group. Information on online media is more segmented for its target audience, from news on politics and economy, sports, lifestyle and even religion which are found in Emtek, TransMedia, and Viva Group. Meanwhile, the media group presents most online media is Kompas Group. As a result, it provides options for the public to enjoy a variety of information through online media.

The next stage is clarifying, which is to convince the media group that a digital platform having all the updated features keeps to be developed in the digital divisions. It has become a necessity when information has entered through the second media age. Competition among media in gaining audience and advertisers today is not only through conventional media but also through new media in the digital platforms.

When it becomes a necessity, the last stage of the implementation process is routinizing. It is where communication technology is clearly recognized and becomes a part of the media group infrastructure. Not only hardware and software development but also training for the media group Human Resources are taken to keep up with the rapid development of communication technology.

The total engagement is obtained by accumulating the number of like and comments obtained in one period when the content is uploaded, that is every month, in the first quarter in 2019. The engagement rate is calculated by dividing the total engagement with the total number of followers of @explorejogja account, and then it is multiplied with 100\%. Referring to the classification of engagement rate for Instagram account, it can be concluded that the engagement rate obtained by @ explorejogja account every month belongs to the level of very high engagement rate, that is over $6 \%$, with the highest engagement rate in January 2019, as much as $11.24 \%$. Meanwhile, the lowest engagement rate is in March 2019, as much as $8.18 \%$.

\section{Social System and Users of Mass Media Digital Platform}

The highest level in the umbrella perspective is the social, political, economic, and media system. Recently, Indonesia has entered into society 5.0. Society 5.0 is a society that can solve social challenges and problems by utilizing various innovations arising in the Industrial Revolution 4.0 era such as the Internet on Things (internet for everything), Artificial Intelligence (artificial intelligence), Big Data (large amounts of data), and robots to improve the quality of human life (Puspita et al., 2020). The entry of the digital platform industry into the mass media has made mass media interaction with its audience possible through the internet. Communication goes both ways, not only between the mass media and the audience but between audiences can be established through the comment column on the digital platform.

Media convergence allows the mass media audience to interact with the mass media and even participate in providing mass media content. Audience can control the time, place, and the ways they access and relate to various kinds of information (Gemiharto, 2015).

The number of digital platform users and their interactions can be used as feedback and evaluation for the content presented by mass media. In economic terms, the use of digital platforms in an internet connection platform can provide income for the groups of mass media group respectively although the income is not as big as from the TV commercial (TVC) for television stations. Based on the interview results with five PIC's of the media digital platforms in Indonesia, it is found that social media has targeted revenue for media companies.

In the umbrella perspective, there is an umbrella handle presenting the users of digital communication technology. Entering the society 5.0, the world community has definitely used internet media to make life easier including obtaining information through mass media. Recently, the internet users in Indonesia in 2020 reaches the number of 175.4 million having a penetration of $64 \%$ of the total Indonesian population which is 272.1 million people. The growth of internet users increases by $17 \%$ from the January 2019-January 2020. These internet users spend 7 hours 59 minutes while television mass media is only watched for 3 hours 4 minutes per day (We Are Social \& Hootsuite, 2020). 


\begin{tabular}{|c|c|c|c|c|c|c|c|c|}
\hline \multirow{2}{*}{$\begin{array}{c}\text { JAN } \\
2020 \\
\#\end{array}$} & \multicolumn{7}{|c|}{$\begin{array}{l}\text { MOST-VISITED WEBSITES (ALEXA) } \\
\text { RANKING OF TOP WEBSITES BY AVERAGE MONTHIY TRAFFCACCORDING TO ALEXA }\end{array}$} & \multirow[b]{2}{*}{ PAGES / VISIT } \\
\hline & WEBSITE & TIME / VISIT & PAGES / VISIT & $\#$ & WEBSITE & & ME / VISIT & \\
\hline 01 & OKEZONE.COM & $5 \mathrm{M} \mathrm{O7S}$ & 4.4 & 11 & IDNTIMES.COM & & $5 \mathrm{M} 015$ & 2.7 \\
\hline 02 & GOOGLECOM & $12 M 095$ & 14.6 & 12 & GOOGLE.CO.ID & & $5 \mathrm{M} 10 \mathrm{~S}$ & 5.9 \\
\hline 03 & TRIBUNNEWS.COM & $3 M 385$ & 1.9 & 13 & MERDEKA.COM & & $3 M 485$ & 2.0 \\
\hline 04 & YOUTUBE.COM & $11 \mathrm{M} 44 \mathrm{~S}$ & 6.7 & 14 & SUARA.COM & & $3 \mathrm{M} 35 \mathrm{~S}$ & 2.2 \\
\hline 05 & DETIK.COM & $8 \mathrm{M} 23 \mathrm{~S}$ & 5.0 & 15 & KUMPARAN.COM & social & $2 \mathrm{M} 45 \mathrm{~S}$ & 1.7 \\
\hline 06 & LPUTANG.COM & $4 M 575$ & 2.3 & 16 & BLOGSPOTCOM & & $3 M 325$ & 2.7 \\
\hline 07 & KOMPAS.COM & $4 \mathrm{M} 20 \mathrm{~S}$ & 2.2 & 17 & YAHOO.COM & & $4 \mathrm{M} 34 \mathrm{~S}$ & 4.4 \\
\hline 08 & GRID.ID & $5 \mathrm{MOBS}$ & 2.4 & 18 & CNNINDONESIACOM & & $3 M 545$ & 2.1 \\
\hline 09 & TOKOPEDIA.COM & $12 \mathrm{M} 23 \mathrm{~S}$ & 7.0 & 19 & BOLASPORT.COM & & $5 \mathrm{M} 50 \mathrm{~S}$ & 3.2 \\
\hline 10 & SINDONEWS.COM & 3м 315 & 2.4 & 20 & KAPANLAGICOM & & $3 \mathrm{M} 30 \mathrm{~S}$ & 3.1 \\
\hline
\end{tabular}

Figure 2. The Most Visited Websites in 2000

(Source: We Are Social \& Hootsuite, 2020)

From the research results, it can be seen that the internet has experienced a very high development. In fact, the duration of the people in using the internet is far above that of television consumption. From the other data, it can be seen that when people are connected to the internet, the most visited websites are the websites serving as the digital platforms for mass media. The table below shows the top 20 websites based on Alexa's research being the part of the mass media digital platform, including: Okezone.com, Tribunnews.com, Detik.com, Liputan6.com, Kompas.com, Grid.Id, Sindonews.com, IDNTimes.com, Merdeka.com, Suara.com, Kumparan.com, CNN Indonesia.com, Bolasport.com, and Kapanlagi.com. 14 out of the 20 most visited websites are news portal websites of media groups in Indonesia.

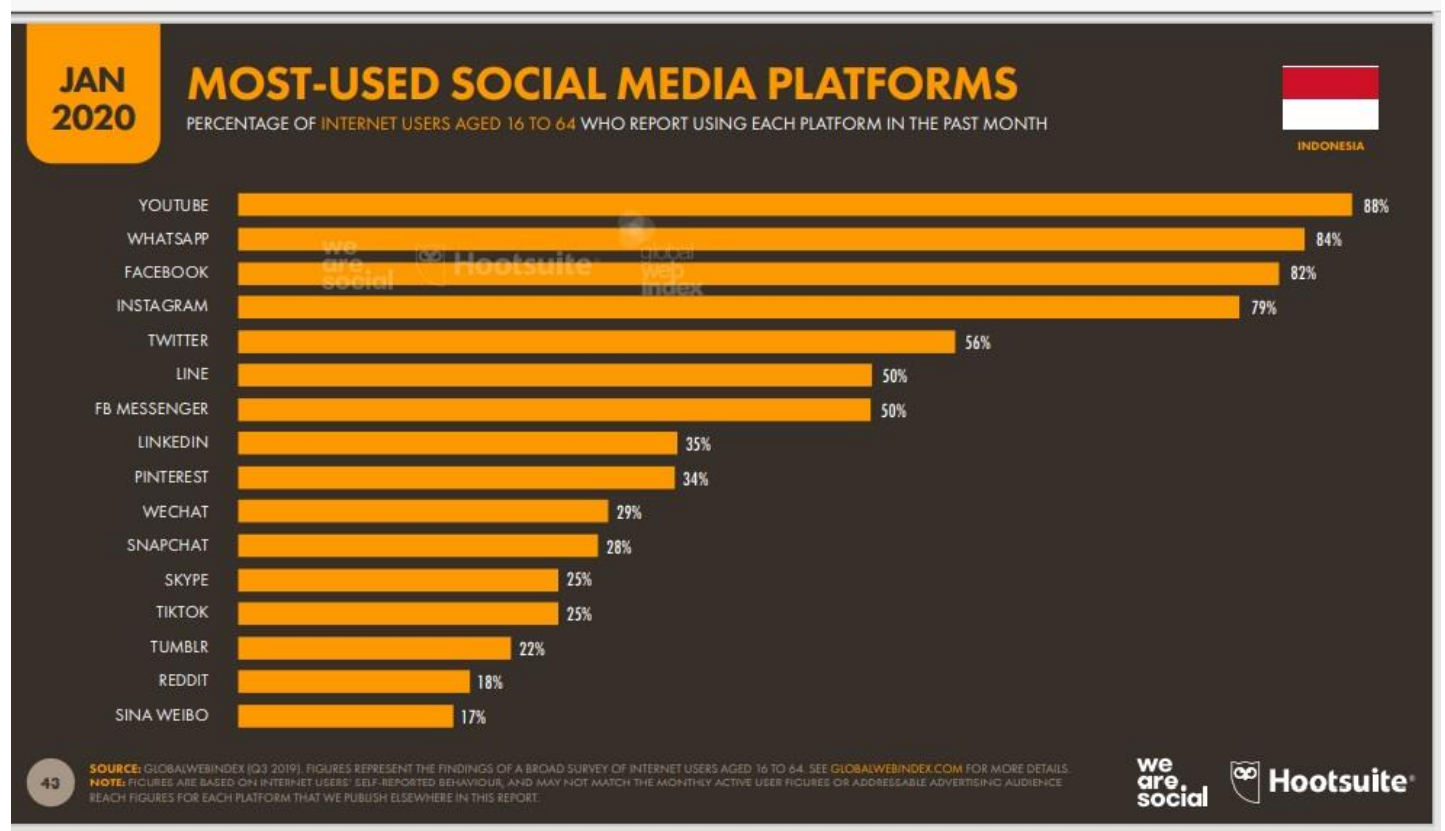

Figure 3. The Most Used Social Media Platform in 2020

(Source: We Are Social \& Hootsuite, 2020) 
The digital platform of mass media attracting the public is social media which is according to the data from Hootsuit showing 160 million social media users in Indonesia. This figure represents 59\% of the total population. In Figure 3 above, it can be seen that YouTube, Facebook, Instagram, and Twitter are the top social media used by the mass media. All forms of media in mass media groups and each of their programs have social media accounts. This digital platform has high engagement creating interactions between the media and the audience as well as the interaction between audience and the audience. The Head of Marketing Digital Content Creative Division of TRANS TV said:

"For a while, we tend to play on YouTube and Facebook. It is because if it is seen from a business perspective, from a platform point of view, we only have zero cost. If we talk about our high demand, if on YouTube, we rank the second highest on television while Trans TV, Trans 7 rank 1. So, if the audience in digital is high. On the website, in my latest data, it is around 300 thousand unit visitors. In Facebook, we are also growing extremely high." (an interview with Mujahid Hanifah, 6 August 2020).

The statement above is supported by the results of interviews with the person in charge of the digital platforms in other media groups. The use of social media in media groups from the media business perspective does have a lower cost than making programs broadcasted on TV and radio stations or articles in printed media. It will definitely benefit the media as an industry. Even with the use of digital platforms, the media industry also gets revenue from advertisers on social media outside of ad revenue from conventional media platforms. The increase in internet users, especially for online media and social media, is based on the research of We Are Social \& Hootsuite in 2020 using the data they have collected. Today's society has reduced television consumption and switched to use digital platforms. Even consuming media on a dual screen basis, people simultaneously get information through conventional media and digital media. When viewing television shows, they also use their mobile phones to interact using the broadcast's social media or search for complete information and even justification of information through cyber media. The growing use of social media in Indonesia has allowed its users to contribute to online discussions, share opinions and feelings, or publish digital creativity.

In this study, the implementation of digital platforms in mass media groups is a form of media convergence. The emergence of the term convergence provides new opportunities for media managers to expand public choices. Convergence also has the opportunity to create a new dominant group that will become the market rulers. One of which is the ownership concentration. Different sectors of the media will join forces and bring the conglomeration to life (Haqqu, 2020). The media conglomeration in this digital era also seems to emerge. Media groups currently do not only have one media platform. However, they expand mass media industry using digital platforms having the convenience of building its infrastructure. These technological advances in the media industry have changed the situation in the field completely. Having relatively low cost, every Internet user can basically create their own media today (Machmud, 2012).

The application of media convergence and redactional convergence in one media is different from other media. The application of convergence depends on the application of information and communication technology used as well as the organization and media policies concerned (Pratopo \& Kusajibrata, 2018). The policies taken by the media groups in Indonesia in the terms of the implementation of digital platforms are seen in terms of economic policies. In addition to the use of digital platforms in line with the development of communication technology, company profits are the major concern. The use of digital social media platforms provides lower costs compared to creating a new digital platform.

The policy in implementing digital platforms in mass media groups is the decision of the media owners. Media owners must have the ability to bring the media industry into the digital era and society 5.0 which is full of business competition. The mass media platform leadership capabilities are: Innovation Capability, Environmental Scanning and Sensing Capability, and Integrative Capability for Media Ecosystems. Integrative abilities play a key role in enhancing the platform leader's ability to gain the value (Helfat \& Raubitschek, 2018). The integrative ability that the media owners can make the right decisions in using digital platforms in the convergence of their media groups entering the media ecosystem, particularly in Indonesia. 


\section{4}

\section{CONCLUSION}

The digital mass media platform as software are websites, online media, applications and social media. In the infrastructure of media organizations, digital platform implementation is a form of media group policy in converting technology, content convergence, and economic convergence. Media groups in this study, namely: TransMedia Group, Kompas Group, MNC Group, Media Group, Emtek Group, Mahaka Group, Viva Group, Netmediatama, and Jawa Pos Group keeps making innovation in digital platforms. The implementation of the digital platform is not only about following technological developments, but it also serves as an economic policy. As the media industry, these media groups use digital platforms because they allocate cheaper production costs and even get other profits other than the income from their conventional media. The development of media platforms experiencing a shift to multiplatform will involve two-way connectivity. The recent media policy strategy focuses not only on content production and distribution, but also on relationship building and maintenance with audiences that are created in the use of digital platforms. These are the considerations having an important part today. The use of digital platforms creates a role for community participation. A digital platform in the form of two-way communication invites a sense of presence and enhances immediacy and involvement in live events. This feature is developed by the broadcasting media industry to exploit audience participation for the purposes of revenue, competitive advantage, and strategic expansion (Ytreberg, 2009). This research is expected to contribute to the study of mass communication and digital communication regarding technological developments and the application of digital platforms in mass media in Indonesia. Further research can be carried out with an analysis focusing only on the implementation of one form of digital platform in mass media.

\section{ACKNOWLEDGEMENT}

The researcher would like to thank Kementerian Riset dan Teknologi / Badan Riset dan Inovasi Nasional (RISTEK-BRIN) Republik Indonesia who has given fund to this research.

\section{REFERENCES}

Dhiya, A., Dan, H., \& Fadilah, E. (2018). Transformasi Harian Kompas Menjadi Portal Berita Digita Subscription Kompas.Id. Jurnal Kajian Jurnalisme, 1(2). http://jurnal.unpad.ac.id/kajianjurnalisme\%7C190

Dianna, D. N. (2020). Dasar-Dasar Penelitian Akademik: Analisis Data Kualitatif dan Kuantitatif. March, 1-10.

Gemiharto, I. (2015). Teknologi 4G-Lte dan Tantangan Konvergensi Media Di Indonesia. Jurnal Kajian Komunikasi, 3(2), 212-220. https://doi.org/10.24198/jkk.vol3n2.10

Gillian, D. (2010). From Television to Multi-Platform: Less from More or More for Less? Convergence, 16 (4), 431-449. https://doi.org/https://doi.org/10.1177/1354856510375145

Haqqu, R. (2020). Era Baru Televisi dalam Pandangan Konvergensi Media. REKAM: Jurnal Fotografi, Televisi, $\quad$ Animasi, $\quad 16(1), \quad 15-20$. http://journal.isi.ac.id/index.php/rekam/article/view/3721

Helfat, C. E., \& Raubitschek, R. S. (2018). Dynamic and integrative capabilities for profiting from innovation in digital platform-based ecosystems. Research Policy, 47(8), 1391-1399. https://doi.org/10.1016/j.respol.2018.01.019

Imran, H. A. (2015). Penelitian Komunikasi Pendekatan Kualitatif Berbasis Teks Communication Research Of Text-Based Qualitative Approach. Jurnal Studi Komunikasi Dan Media, 19(1), $129-139$.

Kencana, W. H. (2014). Konvergensi Media ( Analisis Institusional Komunikasi Bisnis Pada Transmedia Group ). Gelanggang, $i$ no.1, 1-15. http://karyailmiah.upiyai.ac.id/index.php?r=view-article\&id=806

Kencana, W. H. (2018). Implementasi Teknologi Komunikasi Pada Platform Digital Media Penyiaran Televisi. In Damayanti (Ed.), Media Massa di Era Disrupsi 4.0. PT Pentas Grafika.

Kriyantono, R. (2014). Teknik Praktis Riset Komunikasi.Jakarta. PT.Kencana Prenadamedia Group.

Kusuma, S. (2016). Posisi Media Cetak Di Tengah Perkembangan Media Online Di Indonesia. Jurnal 
InterAct, Vol.5, No., 56-71.

Lestari, R. D. (2019). Shifting Journalistic Ethics in the Internet Age, Case Study: Violation of Journalistic Ethics in Journalistic Products and Journalist Behavior in Online Media. Komunikator, 11(2), 142-150. https://doi.org/10.18196/jkm.112027.

Machmud, M. (2012). Perkembangan Teknologi Dalam Industri Media. Jurnal Teknik Industri, 12(1), 57. https://doi.org/10.22219/jtiumm.vol12.no1.57-64

Mikos, L. (2016). Digital media platforms and the use of TV content: Binge watching and video-ondemand in Germany. Media and Communication Journal, 4(3A), 154-161. https://doi.org/10.17645/mac.v4i3.542

Nurudin. (2017). Perkembangan Teknologi Komunikasi. Raja Grafinfo Persada

Pratiwi, M. R. (2014). Peran ICT bagi Organisasi Media Massa dan Budaya Masyarakat. Jurnal Komunikator, 6(1), 20-26. http://journal.umy.ac.id/index.php/jkm/article/view/212/174

Pratopo, W. M., \& Kusajibrata, N. (2018). Konvergensi di Ruang Redaksi pada Kelompok Media Tempo. Jurnal Studi Komunikasi (Indonesian Journal of Communications Studies), 2(1). https://doi.org/10.25139/jsk.v2i1.510

Puspita, Y., Fitriani, Y., Astuti, S., \& Novianti, S. (2020). Selamat Tinggal Revolusi Industri 4.0, Selamat Datang Revolusi Industri 5.0 | Puspita | Prosiding Seminar Nasional Program Pascasarjana Universitas PGRI Palembang. Prosiding Seminar Nasional Pendidikan Program Pascasarjana Universitas Pgri Palembang, 122-130. https://jurnal.univpgripalembang.ac.id/index.php/Prosidingpps/article/view/3794/3565

Respati, W. (2014). Transformasi Media Massa Menuju Era Masyarakat Informasi di Indonesia. Humaniora, 5(1), 39-51. https://doi.org/10.21512/humaniora.v5i1.2979

Setiawan, A., Wibowo, A., \& Florensia, B. F. (2015). Analisis Model Enterprise Architecture Pada Sebuah Stasiun Televisi. http://www.bkstm.org/sites/default/files/upload/Seminar20Nasional20Pendidikan20Tinggi20 2015.pdf

Tapsell, R. (2015). Platform convergence in Indonesia: Challenges and opportunities for media freedom. Convergence, 21(2), 182-197. https://doi.org/10.1177/1354856514531527

Tapsell, R. (2017). Media Power in Indonesia: Oligarchs, Citizens and the Digital Revolution. Rowman\&Littlefield International Ltd.

We Are Social \& Hootsuite. (2020). Digital 2020. In Global Digital Insights. https://doi.org/https://datareportal.com/reports/digital-2020-global-digital-overview

Ytreberg, E. (2009). Extended Liveness And Eventfulness In Multi-Platform Reality Formats. New Media \& Society, 11(4), 467-485. https://doi.org/10.1177/1461444809102955 